\title{
PENERAPAN MEDIA PEMBELAJARAN INTERAKTIF PADA MATA PELAJARAN SISTEM PENGAPIAN SEBAGAI UPAYA MEMBANTU BELAJAR SISWA KELAS XI TEKNIK SEPEDA MOTOR (Studi Kasus: SMK Bina Mandiri)
}

\author{
Wildan Mubarok Azzakki ${ }^{1)}$, Dwi Krisbiantoro ${ }^{2)}$ \\ ${ }^{1), 2)}$ Informatika Universitas AMIKOM Purwokerto \\ email : azzakki02@gmail.com $^{1)}$, dwikris@amikompurwokerto.ac.id $^{21}$
}

\begin{abstract}
Abstraksi
Multimedia pembelajaran interaktif dapat dijadikan sebuah metode pembelajaran yang dapat membantu dunia pendidikan salah satunya tentang sistem pengapian. Penelitian ini dilaksanakan di kelas XI SMK Bina Mandiri yang bertujuan untuk menghasilkan suatu aplikasi sistem pengapian berbasis android menggunkan software adobe animate yang dapat membantu siswa dalam proses pembelajaran. Pengumpulan data dengan menggunakan metode observasi, wawancara, studi pustaka, dokumentasi, dan kuisioner. Hasil yang diperoleh dari penelitian ini yaitu keberhasilan dalam uji coba pembuatan aplikasi multimedia pembelajaran interaktif sistem pengapian berbasis Android yang dibuat menggunakan metode MDLC (Multimedia Development Life Cycle) sebagai media pembelajaran. Media pembelajaran ini sudah dilakukan uji coba. Pengujian dalam penelitian ini menggunakan pengujian Alpha dan pengujian Beta, dalam pengujian Alpha menunjukan hasil tampilan materi dapat menampilkan visualisasi gambar yang sesuai dengan materi dalam buku dan hasil dari perhitungan skala Likert dalam pengujuan Beta yang diperoleh 93\% yang termasuk kategori baik.
\end{abstract}

Kata kunci: Media pembelajaran, Adobe Animate, Sistem Pengapian, Android.

\begin{abstract}
Interactive multimedia learning can be used as a learning method that can help the world of education, one of which is the ignition system. This research was conducted in class XI SMK Bina Mandiri which aims to produce an Android-based ignition system application using Adobe Animate software that can help students in the learning process. Collecting data using the method of observation, interviews, literature study, documentation, and questionnaires. The results obtained from this study are the success in trials of making interactive learning multimedia applications for Android-based ignition systems made using the MDLC (Multimedia Development Life Cycle) method as a learning medium. This learning media has been tested. Testing in this study uses Alpha testing and Beta testing, in Alpha testing shows the results of the display of the material can display image visualizations that are in accordance with the material in the book and the results of the Likert scale calculation in Beta testing obtained 93\% which is included in the good category.
\end{abstract}

Keywords: Learning media, Adobe Animate, Ignition System, Android

\section{Pendahuluan}

Media pembelajaran sebagai alat bantu yang digunakan oleh guru untuk menyampaikan materi kepada peserta didik secara efektif dan efisien sesuai dengan tujuan yang diharapkan [1]. Pemilihan media dalam pembelajaran yang disesuaikan dengan tujuan pembelajaran, karakteristik siswa, latar belakang siswa, dan sebagainya. Pentingnya pemilihan media pembelajaran yaitu untuk meningkatkan kualitas pembelajaran sehingga tercapai tujuan pembelajaran yang diharapkan [2]. Salah satu pengembangan media pembelajaran yang banyak digunakan saat ini yaitu media pembelajaran interaktif. Metode yang dibutuhkan dalam media pembelajaran interaktif salah satunya menggunakan pengembangan perangkat lunak seperti Multimedia Development Life Cycle (MDLC). Sejalan dengan penelitian yang telah dilakukan oleh Mustika, dkk bahwa metode
MDLC yang digunakan untuk membuat aplikasi melalui enam tahapan antara lain: concept, desain, material collecting, assembly, testing, dan distribution [3]. Beberapa tahap tersebut tidak harus dilakukan dengan berurutan kecuali pada tahap concept. Hal tersebut dikarenakan pada tahap concept harus dilakukan paling awal.

Media pembelajaran interaktif salah satunya dapat diterapkan pada materi sistem pengapian. Sistem pengapian merupakan susunan dari beberapa teknologi berkaitan dengan mesin yang digunakan untuk menyalurkan energi listrik dengan input tegangan yang rendah untuk disalurkan menuju ke busi sehingga menyebabkan terjadinya percikan api. Proses terjadinya percikan api tersebut hanya terdapat pada mesin dengan berbahan bakar bensin.

Kesulitan yang biasanya dialami oleh siswa pada mata pelajaran sistem pengapian CDI AC dan DC antara lain siswa masih kesulitan untuk memahami 
fungsi dari tiap komponen. Siswa juga kesulitan melakukan perawatan yang benar. Di samping itu, ketersediaan media pembelajaran masih terbatas dan belum adanya pengembangan media yang sesuai. Selain itu, keberhasilan siswa dalam mata pelajaran sistem pengapian teknik sepeda motor dipengaruhi beberapa faktor. Faktor keberhasilan tersebut antara lain adanya interaksi dalam kegiatan pembelajaran. Interaksi ini mengacu pada interaksi antara guru dan siswa maupun interaksi siswa satu dengan siswa yang lainnya. Selain itu, faktor keberhasilan lainnya yaitu ketepatan pemilihan media pembelajaran [4].

Berdasarkan hasil wawancara yang dilakukan dengan guru teknik sepeda motor di SMK Bina Mandiri menunjukan rendahnya nilai siswa disebabkan oleh beberapa hal, antara lain: (1) metode belajar yang masih bersifat abstrak sehingga siswa sukar untuk mengikuti pembelajaran, (2) pembelajaran yang masih berpusat pada buku modul sehingga kurang memberikan pengalaman bagi siswa, dan (3) tidak tersedianya media untuk melakukan simulasi sistem pengapian. Tentunya permasalahan tersebut mengakibatkan tidak efektifnya dalam proses pembelajaran. Dengan bantuan media pembelajaran interaktif diharapkan dapat membantu proses belajar siswa, sehingga siswa lebih aktif dalam belajar dan dapat memahami materi dengan lebih mudah.

Tujuan dari penelitian ini yaitu menghasilkan aplikasi sistem pengapain berbasis android dengan menggunakan software Adobe Animate yang dapat membantu siswa kelas XI teknik sepeda motor SMK Bina Mandiri dalam proses pembelajaran.

\section{Tinjauan Pustaka}

Penelitian sebelumnya yang dilakukan oleh Herman, dkk pada 2021 memiliki tujuan penelitian untuk melakukan uji coba media pembelajaran mobile learning berbasis andorid sehingga mengetahui kelayakannya. Selain itu, penelitian ini untuk mengetahui tingkat keefektifan penggunaan mobile learning pada materi sistem pengapian. Penelitian ini menggunakan metode Reasearch and Development (R\&D). Hasil yang diperoleh dari penelitian ini adalah hasil uji coba dinyatakan valid sehingga media pembelajaran mobile learning sistem pengapian dinyatakan layak digunakan karena rata-rata dari kedua uji validasi sebesar 96\%. Persamaan dari penelitian ini yaitu sama-sama membahas tentang materi sistem pengapian. Perbedaannya adalah model pengembangan sistem yang dipakai pada penelitian sebelumnya menggunakan model R\&D (Research and Development). Sedangkan peneliti menggunakan metode MDLC (Multimedia Development Life Cycle) [5].

\section{Metode Penelitian}

Seluruh alur atau proses dari penelitian ini dapat dilihat pada gambar 1 berikut ini.

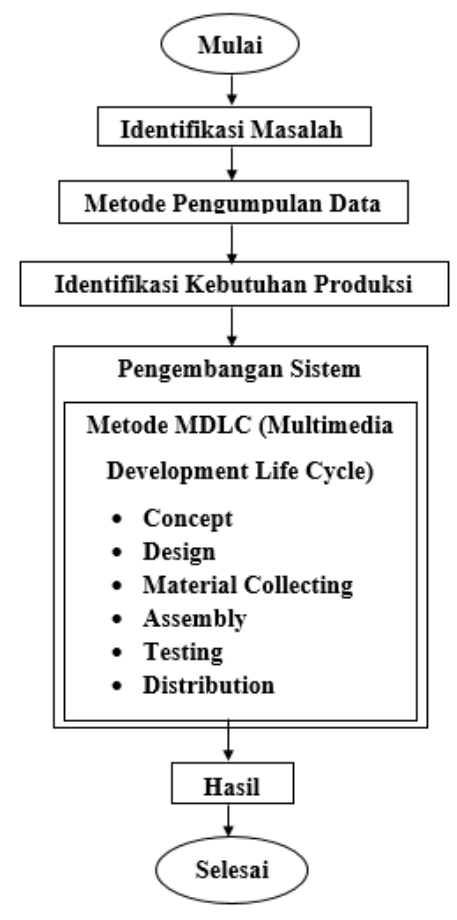

Gambar 1. Tahapan Penelitian

Tahap identifikasi masalah merupakan tahap awal yang peneliti lakukan untuk mengidentifikasi masalah pada objek yang diteliti dan merumuskan permasalahan untuk dijadikan latar belakang dalam penelitian yang dilakukan.

Metode pengumpulan penelitian yang digunakan pada penelitian ini yaitu observasi, wawancara, studi pustaka, kuisioner dan dokumentasi. Observasi yang dilakukan dalam penelitian dengan cara mengamati terkait dengan media pembelajaran yang digunakan, kondisi siswa, dan sebagai upaya pengenalan siswa/siswi SMK Bina Mandiri yang menjadi objek penelitian. Pengamatan yang dilakukan tersebut diharapkan dapat menentukan media pembelajaran interaktif yang sesuai dengan kondisi siswa. Peneliti melakukan wawancara kepada salah satu guru teknik sepeda motor SMK Bina Mandiri. Hal tersebut dilakukan untuk memperoleh informasi secara langsung terkait pembelajaran yang dilaksanakan di SMK Bina Mandiri. Metode pengumpulan data yang digunakan lainnya yaitu studi kepustakaan ini berkaitan dengan pengumpulan informasi yang dibutuhkan dengan sebanyak-banyaknya terutama pada materi sistem pengapian. Referensi yang digunakan dalam penelitian ini berasal dari jurnal, artikel, dan hasil penelitian sebelumnya.

Setelah tahapan identifikasi masalah dan pengumpulan data selesai dilakukan, tahapan selanjutnya adalah identifikasi kebutuhan produksi. Peneliti mengidentifikasi kebutuhan yang digunakan untuk penelitian. Kebutuhan produksi 
berkaitan dengan perangkat keras (hardware), perangkat luunak (software), dan bahan penelitian yang digunakan untuk membuat aplikasi untuk digunakan sebagai media pembelajaran interaktif berbasis android.

Selanjutnya peneliti mulai membangun system dengan menggunakan metode MDLC (Multimedia Development Life Cycle).

Metode Multimedia Developtment Life Cycle (MDLC) mempunyai 6 tahapan yaitu, pengonsepan, perancangan, pengumpulan bahan, pembuatan, pengujian (testing), pendistribusian (distribution). Tahapan tersebut dalam pelaksanaannya tidak harus urut, kecuali tahap pengonsepan harus dilakukan di awal [3]. Berikut gambar terkait tahapan yang terdapat pada MDLC:

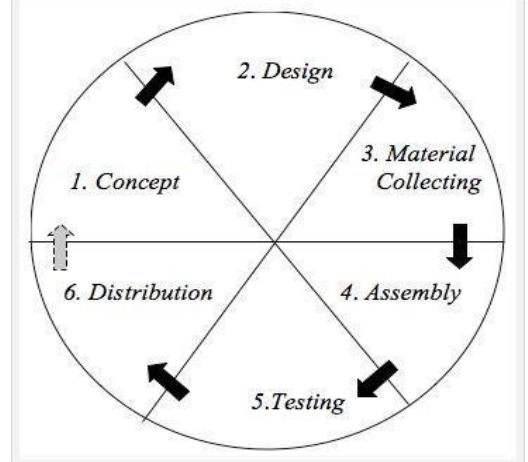

Gambar 2. Multimedia Development Life Cycle

\section{Concept (pengonsepan)}

Tahap ini berkaitan dengan penentuan tujuan, sasaran dari program yang akan dibuat oleh peneliti, aplikasi yang akan dibuat.

\section{Design (perancangan)}

Tahap ini berkaitan dengan menyusun secara rinci hal yang berkaitan dengan pembuatan aplikasi sebagain media pembelajaran interaktif berbasis andorid.

\section{Material Collection (pengumpulan materi)}

Pengumpulan materi dapat dilakukan secara paralel dengan tahap pembuatan. Pada tahap ini peneliti mengumpulkan materi yang dibutuhkan untuk penelitian.

\section{Assembly (pembuatan)}

Tahap pembuatan didasarkan pada tahap desain, dimana perancangan yang telah disusun sebelumnya diterapkan pada tahap ini yang berkaitan dengan bahan multimedia dan pembuatan aplikasi yang digunakan untuk media pembelajaran interaktif.

\section{Testing (pengujian)}

Tahap ini dilakukan saat pembuatan aplikasi telah selesai. Peneliti menjalankan program yang telah dibuat tersebut kemudian mengamati apakah terjadi adanya kesalahan pada program tersebut. Pengujian yang digunakan pada penelitian ini menggunakan pengujian alpha (alpha test). Pengujian ini dilakukan oleh peneliti atau lingkungan pembuatannya sendiri.

\section{Distribution (pendistribusian)}

Tahap ini peneliti menyimpan aplikasi yang telah dibuat, kemudian disimpan pada media penyimpanan. Jika penyimpanan yang tersedia kapasitasnya tidak mencukupi, maka peneliti akan melakukan kompresi aplikasi.

\section{Hasil dan Pembahasan}

Penelitian ini dilaksanakan di SMK Bina Mandiri kelas XI teknik sepeda motor tahun pelajaran 2020/2021. Penelitian yang dilaksanakan bertujuan untuk menghasilkan aplikasi berbasis Android sebagai media pembelajaran interaktif pada materi sistem pengapian. Adanya media pembelajaran ini siswa dapat melakukan aktifitas belajar dengan mudah dimanapun dan kapanpun dibandingkan dengan menggunakan buku yang notabennya berbentuk kertas. Aplikasi ini diharapkan dapat memberikan kemudahan kepada siswa untuk memahami materi pembelajaran.

Berikut tahap-tahap dari metode pengembangan sistem [3] :

\section{Concept (pengonsepan)}

Media pembelajaran sistem pengapian ini dirancang untuk siswa SMK khusunya siawa kelas XI SMK Bina Mandiri. Media pembelajaran ini dijalankan dengan tujuan dapat membantu proses belajar. Selain itu, siswa diharapkan memiliki motivasi untuk belajar dengan lebih baik. Materi pembelajaran yang digunakan merupakan materi sistem pengapian, dimana konsep dari media pembelajaran yang dibuat terdiri dari halaman awal yaitu, tujuan, materi, evaluasi, dan profil. Media pembelajaran interaktif ini dijadikan dalam bentuk android yang dibuat menggunakan software Adobe Animate, tampilan awal yang terdapat dalam media pembelajaran interaktif ini seperti: tombol tujuan yang berisi kompetensi dasar, tombol media yang berisi tentang materi pembelajaran dan simulasi sistem pengapian CDI AC dan DC, tombol evaluasi yang berisi tentang soal, dan tombol profil yang berisi profil.

\section{Design (perancangan)}

Perancangan dilakukan setelah melaksanakan tahap konsep. Perancangan atau design sebagai tahapan untuk pembuatan media pembelajaran interaktif. Proses yang terjadi di tahap design adalah pembuatan storyboard.

Storyboard digunakan untuk menggunakan rancangan atau gambaran dari setiap scene. Berikut ini disajikan storyboard yang digunakan sebagai perancangan untuk memberikan gambaran dalam pada tahap assembly.

a. Menu awal

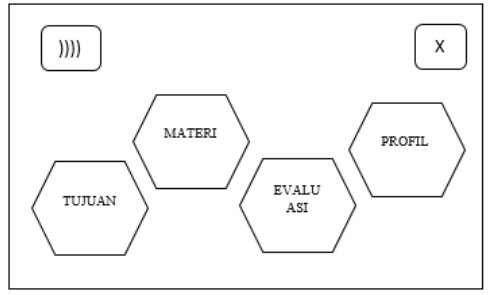

Gambar 3. Menu awal 
Gambar 3 merupakan menu awal. Pada menu ini terdapat Tombol Tujuan, Tombol materi, Tombol Evaluasi, Tombol Profil, Tombol Suara dan Tombol Shutdown.

b. Menu simulasi

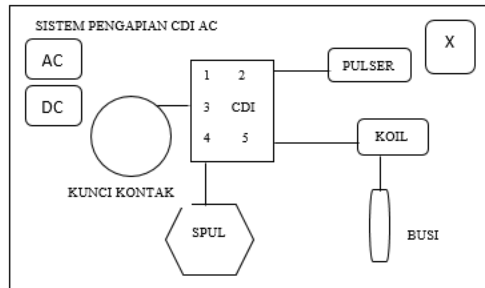

Gambar 4. Simulasi

Gambar 4 merupakan simulasi sistem pengapian CDI AC. Pada menu ini terdapat Tombol AC, Tombol DC dan Tombol exit.

c. Menu evaluasi

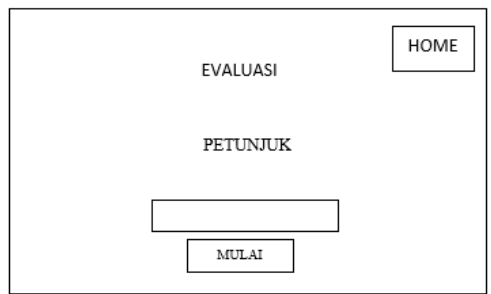

Gambar 5. Evaluasi

Gambar 5 merupakan menu evaluasi. Pada menu ini terdapat petunjuk untuk mengerjakan soal, input text, Tombol Mulai dan Tombol Home.

\section{Material Collection (pengumpulan materi)}

Tahap berkaitan dengan pengumpulan bahan yang digunakan untuk keperluan pembuatan multimedia interaktif. Bahan yang digunakan pada media pembelajaran ini adalah gambar, suara, teks, dan lain-lain yang digunakan sebagai bahan pendukung. Sebagian besar gambar dibuat menggunakan CorelDraw. Untuk suara mengambil download di internet dan background mengambil dari freepik.

\section{Assembly (pembuatan)}

Pembuatan multimedia interaktif pada Adobe Animate. Media pembelajaran yang dibuat disesuaikan dengan storyboard yang telah dibuat pada tahap sebelumnya yaitu tahap desain. Berikut ini merupakan tampilan yang terdapat pada aplikasi:

a. Pembuatan menu utama

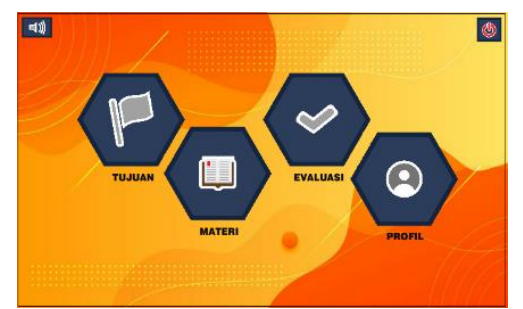

Gambar 6. Pembutan menu utama

Gambar 6 merupakan halaman utama yang terdapat pada aplikasi media interaktif. Pada menu inti terdapat 6 tombol button yaitu: tombol tujuan untuk menuju halaman tujuan, tombol materi untuk menuju halaman materi, tombol evaluasi untuk menuju halaman evaluasi, tombol profil untuk menuju halaman profil, tombol suara untuk mematikan atau menghidupkan suara backsoaund dan tombol shutdown untuk keluar dari aplikasi.

\section{b. Pembuatan menu simulasi}

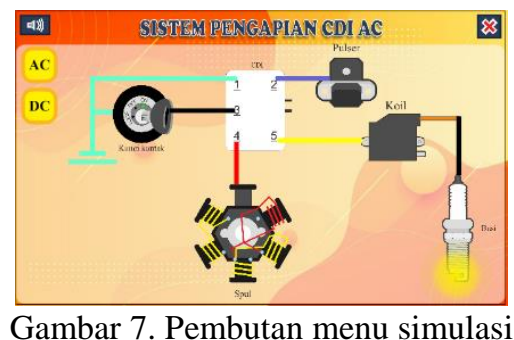

Gambar 7 merupakan menu halaman simulasi pada aplikasi media pembelajaran interaktif. Pada menu ini terdapat 3 tombol button yaitu: tombol ac untuk menjalankan simulasi sistem pengapian CDI AC, tombol dc untuk menjalankan simulasi sistem pengapian CDI DC dan tombol exit untuk menuju halaman materi.

\section{c. Pembuatan tampilan menu evaluasi}

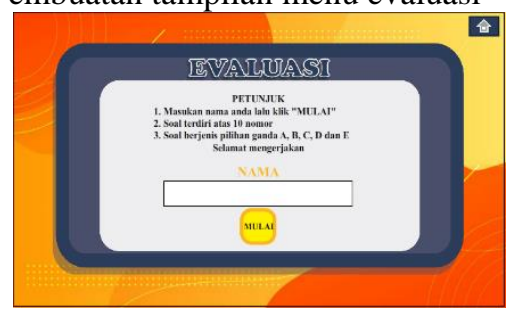

Gambar 8. Pembuatan menu evaluasi

Gambar 8 merupakan menu halaman evaluasi pada aplikasi media pembelajaran interaktif. Pada menu ini terdapat input text untuk mengisikan nama, terdapat tombol button mulai untuk memulai mengerjakan soal dan tombol button home untuk kembali ke halaman awal atau home.

\section{Testing (pengujian)}

Pengujian terhadap multimedia interaktif sistem pengapian dilakukan secara mandiri oleh peneliti sebagai pembuat multimedia interaktif, pengujian dilakukan menggunakan perangkat komputer. 
Berikut adalah hasil dari pengujian alpha test pada multimedia interaktif.

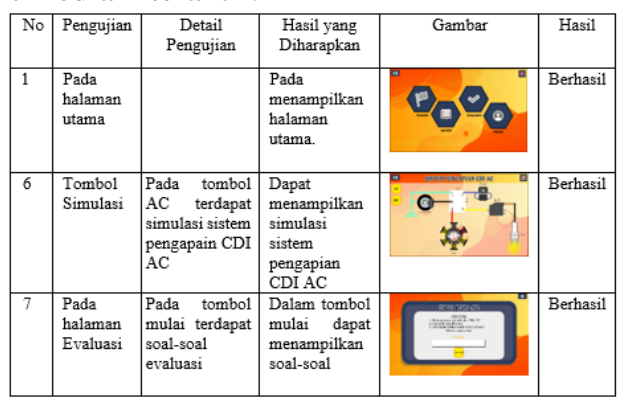

Gambar 9. Pengujian alpha

Dari gambar pengujian alpha yang dilakukan pada gambar 9 diatas maka dapat ditarik kesimpulan bahwa dalam pembuatan media pembelajaran interaktif tidak mengalami kesalahan system dan sudah memenuhi semua fungsionalnya sehingga dapat menampilkan hasil yang diharapkan.

\section{Distribution (pendistribusian)}

Setelah media pembelajaran interaktif sistem pengapian berbasis android selesai diujikan, maka tahap berikutnya adalah pendistribusian. Tahap ini dimulai dengan menyimpan multimedia interaktif dalam perangkat android dalam bentuk format apk. Pendistribusian ini dilakukan secara langung dengan guru teknik sepeda motor SMK Bina Mandiri.

\section{Kesimpulan dan Saran}

Berdasarkan hasil penelitian mengenai aplikasi sistem pengapian berbasis android menggunakan software adobe animate maka dapat di tarik kesimpulan sebagai berikut:

1. Penelitian ini telah berhasil membuat multimedia pembelajaran interaktif pada mata pelajaran sistem pengapian berbasis android menggunakan software adobe animate.

2. Berdasarkan hasil pengujian pada media pembelajaran interaktif ini menggunakan pengujian alpha yang menunjukan hasil tampilan dapat menampilkan visualisasi gambar.

Media pembelajaran sistem pengapian berbasis android ini masih kurang sempurna. Adapun saran untuk penelitian selanjutnya, mengenai pengembangan media pembelajaran interaktif sebgai berikut:

1. Perlu adanya penambahan fitur alat peraga video animasi untuk melengkapai aplikasi sistem pengapian.

2. Agar kedepannya aplikasi dapat dikembangkan dalam versi 3D, supaya visualisasi lebih nyata.

\section{Daftar Pustaka}

[1] A. Y. Utomo and D. Ratnawati, "Pengembangan Video Tutorial Dalam Pembelajaran Sistem Pengapian Di Smk," Taman Vokasi, vol. 6, no. 1, p. 68, 2018, doi: 10.30738/jtvok.v6i1.2839.

[2] M. Pritandhari, "PENERAPAN KOMIK STRIP
SEBAGAI MEDIA PEMBELAJARAN MATA KULIAH MANAJEMEN KEUANGAN MAHASISWA UNIVERSITAS MUHAMMADIYAH METRO," PROMOSI (Jurnal Pendidik. Ekon., vol. 4, no. 2, Dec. 2016, doi: $10.24127 /$ ja.v4i2.631.

[3] M. Mustika, E. P. A. Sugara, and M. Pratiwi, "Pengembangan Media Pembelajaran Interaktif dengan Menggunakan Metode Multimedia Development Life Cycle," J. Online Inform., vol. 2, no. 2, p. 121, Jan. 2018, doi: 10.15575/join.v2i2.139.

[4] F. Fatkhannudin and S. Suwahyo, "Pengaruh Penggunaan Modul Pembelajaran Interaktif Terhadap Hasil Belajar Kompetensi Sistem Pengapian Konvensional," Jurnal Pendidikan Teknik Mesin Unnes, vol. 12, no. 1. p. 125925, 2012.

[5] R. Wijaya, S. Suratno, and H. Budiyono, "PENGEMBANGAN MEDIA PEMBEJARAN MOBILE LEARNING BERBASIS APLIKASI ANDROID PADA MATERI SISTEM PENGAPIAN SEPEDA MOTOR," $J . \quad$ Ilmu Manaj. Terap., vol. 2, no. 4, pp. 513-523, Mar. 2021, doi: 10.31933/jimt.v2i4.462. 